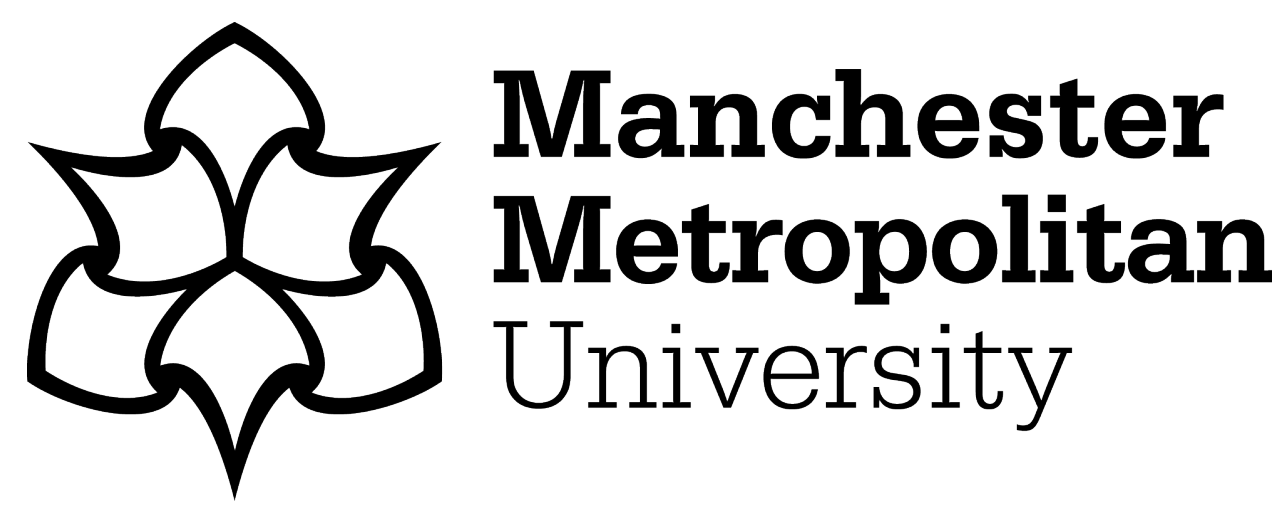

Papadopoulos, Orestis ORCID logoORCID: https://orcid.org/0000-00015086-5086 and Lyddon, Dave (2020) Deregulation and institutional conversion in the Greek hotel industry: an employment relations model in transition. Industrial Relations Journal, 51 (1-2). pp. 92-109. ISSN 0019-8692

Downloaded from: https://e-space.mmu.ac.uk/625118/

Version: Accepted Version

Publisher: Wiley

DOI: https://doi.org/10.1111/irj.12282

Please cite the published version 


\title{
Deregulation and institutional conversion in the Greek hotel industry: an employment relations model in transition
}

\begin{abstract}
Before the debt crisis of 2010 forced Greece into almost permanent austerity, its hotel workers enjoyed wages and conditions (through a sector collective agreement) similar to those in other economic sectors. This was against the international trend where low wages and poor conditions were standard. Sweeping deregulation by Greek governments has brought much of the hotel industry into line with other countries. The sector agreement, now covering a much smaller proportion of the workforce, survived but has experienced 'institutional conversion', delivering a much poorer outcome. Despite buoyant tourism, institutional deregulation and derogation have delivered the employers' major objective of matching the workforce to the fluctuating demand for labour.
\end{abstract}

Keywords: hotel industry, economic crisis, flexibility, deregulation, institutional conversion

\section{INTRODUCTION}

I have been working in hotels since 2017 . The working conditions are extremely intense and exploitative. I am getting very stressed. I am also working long hours because we are short of staff, but no overtime is paid. My salary is very low, and no career prospects are on the horizon (27-year-old male, seasonal receptionist, non-union 5-star hotel, Santorini).

Before the eruption of the crisis in 2010, hours were fully compensated according to the sector agreement. I used to have a stable working pattern without much fluctuation. My salary could reach $€ 1500$ per month which was almost double than the then minimum wage rate (53year-old female, full-time permanent cleaner, unionised 5-star hotel, Athens). 
The first quote expresses the current experience of hotel workers in Greece (as reported, for example, in TV Focus on People, 2017) and reflects the image of hotel work found by most studies internationally. This literature suggests that hotels in both high-end and medium-level product markets traditionally rely on low-skilled and casualised workers, who face poor and unpleasant working conditions, insecurity and low pay (Wood, 1997; Bernhardt et al., 2003; Lucas, 2004; Baum, 2019). Work intensification, limited job control, high work demands, and employee stress are increasingly reported due to the prevalent cost-cutting strategies adopted by hotels, exacerbated by weak union presence, lack of multi-employer agreements and violations of labour rights (Brown and Crossman, 2000; Baum, 2006; Warhurst et al., 2008; Vanselow et al., 2010; Casado-Díaz and Simon, 2016). Work organisation has not changed much in recent years, with automation and investment in skills being limited, especially in certain occupations (such as cleaning) (Zampoukos and Ioannides, 2011, 32). Flexible work arrangements - such as temporary, part-time, agency and outsourcing/subcontracting - are on the rise, substituting for permanent full-time staff and responding to the 'naturally' fluctuating occupancy rates of the industry (Warhurst et al., 2008; Lai et al., 2008; ILO, 2010). Seasonality and informality are also prominent features, especially in summer destinations that employ (mainly female, migrant or young) workers for only half of the year or less (Adam-Smith et al., 2003; Robinson et al., 2019). As a result, many tend not to stay in the industry, but female, migrant and young workers provide continuous pools of labour resources, reducing hotel employers' interest in developing skills and providing training to avoid high labour turnover (Appelbaum, 2010, 199).

The second quote challenges the argument that the hotel industry is always low-paid, acknowledging the long-standing role in Greece of a multi-employer sector collective agreement in determining workers' terms and conditions and improving job quality. Following Dunlop $(1958,94)$, while the technical and market contexts of an industry (such as hotels) may be similar internationally, the 'power context' and the 'status of the actors' - 'workers and their organizations, managerial hierarchies, and governmental agencies' - vary significantly. Working conditions and wage levels in hospitality are not particularly good in most countries because the weak and infrequent union 
presence makes the enforcement of any collective agreements difficult (Appelbaum, 2010, 199). Even in France and the Netherlands, with legally binding multi-employer agreements, working conditions in hotels are not superior to the USA or the UK which lack multi-employer agreements (Vanselow et al., 2010).

Such findings, along with others referred to below (for example, Jaehrling and Méhault, 2012; Cañada, 2018; Godino and Molina, 2019), illustrate the limited role of external regulation across much of Europe in improving the job quality and earnings of hotel workers. Consequently, research on hotel work has paid little attention to collective agreements, assuming their role to be limited or irrelevant. But, in Greece, the tradition of sectoral regulation in the hotel industry was strong and continued even during the economic crisis (Koukiadaki and Grimshaw, 2016). Our main research objective therefore is to establish whether and how the maintenance of the sectoral agreement since the crisis has mitigated deregulation pressures in the national labour market. In the process, we examine how, and to what extent, national deregulation has enabled hotel employers to circumvent sectoral regulation, and whether the power context (particularly, workplace union presence) can still influence positively workers' terms and conditions. To do this, we not only analyse national labour market reforms and the changing sectoral agreement, but also workers' experiences in upper-market hotels in Athens and on several Greek islands; we assume that such workplaces are more likely to follow sectoral regulation and avoid a race to the bottom.

The article is structured in the following way. The next section situates the hotel industry within the Greek employment model before 2010 , when the national austerity programme started. The Greek tourist sector has grown absolutely and relatively since then but has not escaped being sucked into the vortex of austerity. The forms that this has taken are conceptualised by using the terms deregulation and derogation, noting particularly the institutional conversion of the continuing sector agreement. The research methods used for gathering data are then outlined. Our most important documentary source is the series of sectoral collective agreements, which chart the 'negotiated' reduction in terms and conditions, along with evidence of the shrinking sectoral coverage of the agreement. This reduction was facilitated by continuous legislative changes liberalising the national labour market. A 
programme of interviews with hotel workers provides rich testimony to illustrate the human consequences of deregulation and derogation. A discussion of employment relations in Greek hotels before the crisis then precedes an account of the national deregulation that arose from the externallyimposed national austerity programme. This latter facilitated the institutional conversion of the sector agreement.

Because of the speed of change, Greece provides an interesting case study of the interaction between national and sectoral contexts. We found that the national context (Dunlop's power context) was the most important factor determining hotel workers' terms and conditions both before and during the crisis. In the pre-crisis period, hotel employers and workers generally followed the Greek employment model, with sectoral regulation and trade union presence. As a result, they stood out against the dominant cost-cutting and low commitment practices internationally (where the technical and market contexts of the hotel industry generally overrode any counter-effects of national power contexts). The crisis unleashed a tsunami of deregulation and derogation such that the Greek hotel industry, apart from important pockets, currently resembles that of other countries where union presence (rather than a supportive national employment model) is the main factor driving any improvement (or resisting deterioration) of pay and conditions. The variation in terms and conditions among the workforce generally resulted from individual employees' contractual status, reinforced by the continuing relevance of workplace unions where they survived.

The Greek case also shows how national labour market reforms, through weakening (but not, in this case, abandoning) sectoral regulation (in other words, institutional conversion), can promote structural interests of hotel employers such as managing demand through a more flexible workforce. The terminology of deregulation and derogation provides a language to explain these profound changes, which we chart through the interaction of legislation, collective agreements, and workers' own voices. 


\section{CHANGES IN THE GREEK EMPLOYMENT MODEL AND THE HOTEL INDUSTRY}

Prior to the eruption of the crisis in 2010, Greece, like other Mediterranean countries, displayed specific labour market features. Employment protection restricted the extensive use of flexible work contracts while sector agreements in several industries, underpinned by the favourability principle and extension mechanisms, covered most workers, ensuring that pay rates were superior to the ones laid down by the National General Collective Agreement (EGSSE) (Currie and Teague, 2017, 164-165). The EGSSE was signed annually by national representatives of workers and employers, stipulating minimum terms of employment (including the national minimum wage, NMW) and operating as a reference point for negotiation at lower levels (Zambarloukou, 2010, 238). The favourability principle ensured that lower-level agreements, such as sector or company ones, could deviate from higher levels only if they contained more favourable terms (Marginson and Welz, 2015, 433). Workers could complain to enforcement agencies in case of violation of the agreement, especially by small and medium-sized hotels that lacked union presence. Prior to 2010, unlike most other countries, Greek hotel workers' wages and employment rights were covered by a sector agreement, while some restrictions on flexible work were also crucial in protecting workers. Because of the extension mechanism - legally binding extension of collectively agreed wages and terms and conditions to all workers in a sector - around 80 per cent of the hotel workforce was covered by the sector agreement (informal employment was outside it) and pay was higher than the NMW. Although common features of the industry internationally, such as long working hours, unpaid overtime and uninsured employment, were evident in Greece, previous accounts (Gialis et al., 2017) have argued that informal-atypical work there took more socially integrated forms with workers tied to interpersonal and family networks that ensured some stable employment trajectory. So the hotel industry contained features found in other Greek industries with different technical and market contexts.

National models tend to oversimplify employment relations since they inadequately account for the complexity, change and variation observed in specific sectors (Meardi, 2004; Bechter et al., 2012). In the pre-crisis period the hotel industry followed the trajectory of the Greek employment model, although it displayed some industry-specific characteristics such as greater informality, seasonality 
and labour turnover. Due to high public deficits and public debt, Greece and its creditors (through the Troika of the International Monetary Fund (IMF), the European Central Bank and the European Commission) agreed, in May 2010, a bail-out of $€ 110$ billion (equivalent to 50 per cent of GDP) (Currie and Teague, 2017). In exchange, Greece implemented an economic adjustment programme, containing fiscal consolidation and internal devaluation goals (European Commission, 2010). The latter was a deliberate attempt by the Greek state to deregulate the labour market in order to reduce unit labour costs and boost economic competitiveness (Karamessini, 2012).

As a result, most Greek industries followed a downwards trajectory in market share, job losses and closures. Tourism and hospitality did not suffer as badly and, since 2013, have benefited greatly from geopolitical changes (terrorist attacks in Egypt, political instability in Turkey) to gain increasing (regional) market share. The direct contribution of Greek tourism to GDP was 11.7 per cent (€21.6 billion) in 2018 compared with 6.7 per cent (€14.8billion) in 2013 . When the indirect benefits are added, the contribution of Greek tourism reached 25.7 per cent in 2018 (€47.4 billion) (INSETE, 2019a). Tourism has become so important that almost half of Greek exports were related to it (INSETE, 2019a). Employment rose, but only by an annual average of 0.9 per cent, in the period 2008-17 (INSETE, 2018), reaching 411,000 in 2018 - almost 11 per cent of the now much reduced total employment compared with around 7.5 per cent in 2010. This included 95,500 hotel workers, many employed by large establishments in Athens, Crete and Rhodes (INSETE, 2019b). In fact, 4-star and 5-star hotels now account for 46 per cent of all hotel rooms and employ almost half of the hotel workforce, but generate 71 per cent of the industry's revenue (INSETE, 2018).

\section{CONCEPTUALISING THE RELATION BETWEEN NATIONAL LABOUR MARKET REFORMS AND SECTOR AGREEMENTS}

The hotel industry is one of very few in Greece where the sector agreement was renewed after 2010 the overall number of such agreements collapsed from 65 in 2010 to 12 just five years later - because of the moderate and non-conflictual relations of the social actors prior to the crisis (Koukiadaki and 
Grimshaw, 2016). But sector agreements can be seriously undermined by deregulation - particularly, reduced employment protection legislation - that liberalise and promote flexible work practices such as temporary, outsourcing, or agency work (Doellgast and Greer, 2007). Baccaro and Howell (2017, 18-19) explain: 'deregulation eliminates constraints upon capital's discretion through the removal of legal or contractual restrictions at the workplace level, in the broader labour market and in society'. More specifically, 'institutional deregulation' can include a 'shift from higher levels of collective bargaining ...; greater recourse to individual bargaining ... or unilateral employer decision-making; a shrinking in the collective organization capacity of class actors; ... lower employment protection'.

In Germany, the use of short-term contracts has increased considerably since the introduction of national policy that encourages the use of 'mini-jobs' and undermines the impact of sector agreements (Appelbaum et al., 2010, 197). Jaehrling and Méhaut (2012) compared the German and French hotel industries among other services and found that sector agreements were not respected due to legal and illegal avoidance loopholes such as flexible work. Similar findings were reported by Cañada (2018) and Godino and Molina (2019) when analysing the impact of outsourcing on hotel chambermaids in Spain. Structural forces inherent in the hotel industry (such as managing fluctuating demand through flexible work arrangements) are likely to reinforce this process, making deregulation the most important policy intervention.

Streeck and Thelen (2005) and Baccaro and Howell (2017) have highlighted also derogation: mechanisms to permit bypassing or ignoring rules, such as through opt-out clauses (exemptions from the law) that, for example in the Greek case, allow employers to move collective bargaining to lower levels. Baccaro and Howell (2017), and Thelen (2009) before them, have also highlighted the plasticity of institutional continuity - when sector agreements are renewed - suggesting that continuity of form can accompany transformation in their content. Using the term institutional conversion, they describe a process in which changes in the power context lead to less favourable terms for employees, despite the formal continuation of sector agreements. .

With the hotel industry closely following, before the crisis, the Greek national model, albeit with the industry's particular features, in the rest of the article we examine how the processes of deregulation, 
derogation and institutional conversion have operated since the crisis. In particular, we are concerned with the extent to which the sectoral agreement has mitigated deregulation in the national labour market and what factors - including industry-wide features and workplace union presence - have been most significant in this.

\section{METHODS}

Fieldwork was conducted in Greece by the first author from December 2017 until January 2019. The most significant documentation gathered was the series of multi-employer collective agreements in combination with the legislative changes enabling the employers to weaken the content of the agreements. Other documentary material included newspaper articles, union press releases, and speeches of union leaders, all a matter of public record. This material charted the 'negotiated' reduction in terms and conditions, complemented by evidence of the shrinking sectoral coverage of the agreement.

A survey of hotel staff, which could have provided first-hand evidence, in practice, of deterioration in wages and other terms and conditions, was deemed impracticable. The problems of achieving a sufficiently representative sample (occupations, workforce demographics, contractual status, location, hotel status, and so on) would likely have been compounded by a problematically low response rate. So we decided upon an interview programme. Rather than attempt to cover all segments of the market, we assumed (as in other studies, Lloyd et al., 2013) that upper-market hotels are more likely to provide better wages and working conditions and therefore attest to the resilience of the sectoral agreement. Although we did not seek out budget hotels, several interviewees reported that wages and working conditions in these places were much worse.

Twenty-three of the interviews were held with workers from mainly large, usually 5-star (some 4-star) hotels. More than half worked in Athens, two others on the mainland, with the rest either from the large island of Crete or from the smaller islands of Corfu and Kefalonia, in the Ionian Sea, and Mykonos, Paros, Rhodes and Santorini, in the Aegean. These regions accounted for 85 percent of the 
total revenue generated by the Greek hotel industry in 2017 (ITEP, 2018) and are therefore representative of the industry as a whole. Interviewing workers from Greek islands allowed us to explore the effects of seasonal work (limited contract duration and short-term horizons) and the traditionally absent, or very low, union presence there, even in upper-market hotels. In Athens large upper-market brand hotels are more likely to be prominent members of the Employers' Association of Tourism Enterprises (SETE, the signatory to the sectoral agreement), a further distinction between hotels in Athens and the islands.

Most interviews took place outside the workplace while those with seasonal workers were held mainly in Athens during the off-peak period. The selection covered most occupational groups, such as cleaners (seven), bartenders, waiters/waitresses (eight), porters, chefs/cooks (four), and receptionists (four). There were four workers over 50 years old, eight between 30 and 49, and eleven under 30 . We interviewed some longer-serving workers (eight with ten or more years' experience) - to compare their pre- and post-crisis experience - and younger ones on flexible contracts. We included union members (nine) and non-unionists (fourteen); seven of the unionists and two non-unionists worked in hotels with union presence, while two non-members were employed in unionised workplaces. There was a range of contractual status: full-time and part-time; permanent (six), temporary (eight), and seasonal (nine). Seasonal workers were included because informality and labour violation are the routes through which collective rights and sector agreements are usually undermined.

To understand the unions' strategies, tactics and choices and how they attempted to mitigate labour market reforms, interviews were also held with the national president of the Pan-Hellenic Federation of Food Workers and Tourism Employees, two of its local union presidents in Athens, and an activist in Crete. Interviews were also conducted with the president and three other leaders of the Syndicate Hotels-Tourism Attika and one group interview of its members at a large 5-star Athens hotel. The Federation (consisting of regional and workplace unions) represents hotel workers and signs the sector agreement; it is widely considered a moderate union focused on social dialogue and consensus bargaining. The Syndicate is the local Athens union, with a strong presence there, and a militantradical outlook. As a minority tendency in the Federation it has no right to participate in sectoral 
collective bargaining. We received significant support from the unions: after interviewing trade unionists we were given contact details of other members, though we were careful also to approach non-unionists to provide a more representative picture because of low union density, especially among the young. The research director of the employers' association, SETE, was also interviewed.

Interviews lasted from 60 to 90 minutes. Their semi-structured form enabled a focus on selected topics as well as expansion on issues raised. Themes included demographics, pay, benefits, employment types, sector agreements, union presence, labour process, and changes since the crisis. The sample of interviewees was clearly not large enough to be considered in any way representative, but it did allow us to explore the reality of the changes since the crisis. Necessarily, only a very limited selection of the interview material from hotel workers could be quoted in the article, but those voices put flesh on the otherwise dry bones of deregulation and institutional conversion. Their testimony reflects the weight of evidence provided from those not cited, matches the analysis of the union officers and activists interviewed, and confirms the pattern and trends we identified from documentary sources, while adding some important insights.

\section{EMPLOYMENT RELATIONS IN HOTELS BEFORE THE CRISIS}

Multi-employer sector agreements between the Federation and SETE were the rule prior to the crisis. The 2004 agreement set out an overall one-year pay rise of 5.5 per cent. It regulated flexible work, such as one-day employment contracts, and provided service benefits for all occupational categories. The next two agreements, in 2005 and 2006, brought pay increases (of around 6 per cent per annum), setting basic pay at 30 per cent higher than the NMW, when fringe benefits were included. Unlike countries where poor enforcement, low union presence in workplaces and strong employers' associations had undermined sector agreements, Greek collective coverage was higher due to the extension mechanisms and favourability principle, union workplace presence, and the slower pace of labour deregulation. According to the Federation president, collective agreements used to reduce 
excessive workloads, occupational risks and violation of labour rights, prescribing in detail rules on breaks, holiday pay and maternity leave, for example.

Yet the country was not unaffected by industry trends internationally, such as increased workloads and cost-cutting strategies that originated from competitive pressures and restructuring. According to a Syndicate committee member, the pre-crisis period 'saw significant changes in workloads as hotels were responding to market pressures. A cleaner would have to clean 18-20 rooms per day from 13-16 some years earlier while the number of amenities also increased'. Likewise, work organisation was close to other countries, with our interviewees describing hotel work generally as hard and very tiring, whose content had changed little over time. Legislative changes during the 1990s (laws 1892/1990 and 2639/1998) relaxed rules on part-time and temporary work, enabling hotels to pursue flexibility and sometimes circumvent sector agreements. The use of 'extras' - employment contracts of one day - was another mechanism to manage fluctuating demand and avoid hiring permanent staff. But Greek employment protection legislation prevented agency and part-time work from becoming as widespread as in other European countries.

Informal employment and violation of labour rights were common features of the Greek model that were reflected in the hotel industry (Adam-Smith et al., 2003; Karamessini, 2008). Especially in seasonal work (tourist regions), we found that informality has always offered a credible route for employers to avoid sector agreements, pursue flexibility, impose low pay and promote uninsured labour. But, as Gialis et al. (2017) argue, this informality was more socially integrated and based on stable employment patterns and relations. Our findings support this view, with temporary contracts less exposed to erratic fluctuations compared with countries such as the UK. The explanation lies in sectoral regulation: article 6 of the 2006 agreement obliged hotels to rehire seasonal workers if they expressed a desire to continue with the same employer (POEET, 2006). As a result, temporary contracts of seasonal workers were renewed annually, with interpersonal relations in small and medium firms also providing some sense of belongingness and stability. The argument of some studies (Robinson et al., 2019, 1016), that those in non-standard employment across Europe and the USA faced substantial wage penalties, was not found in Greece. The comment below, from a 50-year- 
old former seasonal bartender with over fifteen years' experience in a large non-union 5-star Rhodes hotel, exemplifies the different trajectory in Greece prior to the crisis, highlighting an industryspecific feature (tips) that previous studies seem to overlook:

Salaries were decent before the crisis and especially tips were very good. I could easily survive on that money during the year. I was working for the same hotel every year since I knew everyone, and everyone knew me. It was hard work, don't get me wrong and, in some occupations, pay was lower and employers aggressive but overall it was much better than today.

Although union density levels were only about 15 per cent in 2007-08 and not very high compared with the rest of the economy, collective organisation was important, especially in large hotels, as unions were able to resist deregulation and represent workers at the workplace. We found cases where militant unions had successfully stopped the introduction of agency work. In a large Athens hotel the local union (affiliated to the Syndicate) mobilised cleaners in 2008 through work stoppages, forcing the management to hire staff on permanent contracts instead of using agency workers. Analogous actions elsewhere created a general counterweight to degradation, illustrating that power relations and collective action were critical for improving job quality even in sectors such as tourism. But austerity and labour reforms seriously weakened unions' ability to protect workers' rights. This is supported by our findings for the post-crisis period.

\section{NATIONAL LABOUR MARKET REFORMS: THE ROLE OF DEREGULATION}

In 2010 an austerity programme (First Memorandum), containing significant changes to labour law, was agreed as a condition for Greece to avoid defaulting on its debts (European Commission, 2010). With the laws $3846 / 2010$ and $3899 / 2010$, there was a significant increase in the period (from eight to 36 months) in which a temporary contract could be renewed before becoming permanent, while parttime wage rates were reduced as were pay levels for agency work not covered by sector agreements (Koukiadaki and Kretsos, 2012). Consequently, part-time and temporary contracts have skyrocketed 
in hotels, representing around 50-60 per cent of the workforce in 2018-19. This reflects wider trends in the Greek economy, where flexible employment has become dominant: it represented 54.3 per cent of new hires across the economy in 2018 compared to only 21 per cent in 2010.

A 21-year-old houseman (temporary, part-time) recently hired by a large non-union 5-star Athens hotel aptly described the consequences: 'my working conditions and pay were much worse than my older colleagues. I was receiving the minimum wage while, when working longer because we were short of staff, no overtime pay was given.' This reflects other interviewees' narratives and supports the argument of previous studies (Berntsen and Lillie, 2015; Arnholtz et al., 2018) that flexible arrangements are used to actively undermine the standards set down in sector agreements, with many workers' experiences being increasingly determined by national-level changes despite seeming sectoral continuity. The Syndicate president suggested that for employers the benefits of using flexible contracts, such as agency work, satisfies an industry-wide goal previously obstructed by national regulatory provisions and sector agreements: reducing numbers to respond to lower demand becomes easier with more employees on flexible contracts. A 55-year-old female (permanent fulltime) cleaner with widespread experience and a member of the local union said that, temporary and rotation contracts were used as substitutes for regular employees in her workplace (a large unionised 5-star hotel in Athens), as the latter were more expensive and less flexible forms of labour, being regulated by the sector agreement. Not all occupations were susceptible to agency or temporary substitution, though, with hotels aware of potential threats to service quality. This corresponds with previous accounts (Schlesinger and Heskett, 1992; Korczynski, 2002) according to which servicesector organizations incorporate into their strategies the goals of efficiency and customer-oriented behaviour, with the latter critical to their success. According to a 52-year-old union member, a fulltime permanent receptionist with over twenty years' experience and currently employed by a large unionised 5-star Athens hotel, agency work was not used at all in her workplace as there were fears that this could undermine service quality, with employees becoming more indifferent about their work. Front-line staff (e.g. receptionists) were less likely to be agency staff but housekeeping positions and waitresses were often recruited through agencies, according to our interviews. 
Even when flexible workers were covered by sector agreements, their wage levels were significantly lower, workloads more unstable and other benefits (such as sick leave and holiday pay) often not applied. A 35-year-old male (full-time but temporary) non-union cook in a large unionised 5-star Athens hotel explained: 'my monthly contract stipulates a minimum of one day's work to a maximum of twenty-five days, so in off-peak seasons I either work very compressed workloads or my contract is not renewed at all.' Temporary workers in Australia, for example, shared similar experiences since continuity of sectoral regulation (award-based regulation) there in a context of deregulation did not prevent them from facing worse employment terms and pay than permanent staff (Knox, 2010, 453). Flexible workers were often not welcomed by permanent staff in Greece, with one local union in a large 5-star Athens hotel clearly against representing them - claiming that they were not part of the hotel and thus organising them was not the union's business. We found, though, that excluding agency workers from unions further limited the impact of sector agreements as a regulatory mechanism and also divided the workforce. Reacting to this situation, unions with the active participation of the Syndicate went on strike in July 2017, mainly over the abolition of agency work and to reinstate the favourability and extension principles so that the sector agreement could be applied to everyone whatever their contractual status (Rizospastis newspaper, 2017a).

In response to the Troika's pressure, in 2012 the government introduced Act 6 of the Ministerial Council that reduced the NMW by 22 per cent (but 32 per cent for those under the age of 25). Following this, the law 4172/2013 stipulated that the determination of the NMW was the government's job and not the outcome of national collective bargaining between the social actors as before the crisis. Many employers stopped engaging with unions, instead using individual employment contracts with pay set at the reduced NMW (Rizospastis newspaper, 2017b). Due to these changes, the Greek economy saw an average reduction of pay levels by 28 per cent in a nineyear period, with the average monthly salary falling from $€ 1,247$ in 2010 to $€ 899$ in 2018 . According to interview evidence and union estimations, wage levels in hotels are close to the average alleconomy level. Although an NMW has been perceived as a positive step establishing a wage floor for the hotel industry in countries such as France, the Netherlands and the UK (Vanselow et al., 2010, 
298), in Greece the NMW reduced the wage floor set by the sector agreement. This finding suggests that Greek governments' deregulatory legislative programme has enabled employers to reduce labour costs and achieve greater flexibility: so governments' role on minimum wages in Greece is not perceived as positively as in some other countries (such as in Warhurst et al., 2008; Lloyd and Payne, 2018).

These changes coincided with the rise of a readily available and cheap hotel workforce, emanating from the economic crisis, the lack of social protection and the prolonged sluggish growth thereafter. Since the crisis, many unemployed or precarious young Athenians have moved to Greek islands or tourist spots on the mainland to work during the summer to earn enough to survive in the winter; though most of them must also work during the winter since hotel work is now so poorly paid (Papanikopoulos et al., 2018). This 'reserve army of labour' has been used by hotels either to recruit directly from or to remind current employees how easily they can be replaced, disrupting in that sense the interpersonal relations and socially-integrated forms of informal employment reported in the precrisis period. Thus, there is little incentive for hotels to improve job quality, respect collective agreements and recruit permanent staff as high labour turnover is no longer their concern. Reflecting feelings expressed by many of our younger interviewees, a 27-year-old (part-time, temporary) waitress in a medium non-union 4-star Athens hotel explained: 'If you complain about low wages they will say if you do not like it then we find someone who moans less as many are waiting to get your job'. The Federation president, describing this employment landscape as 'terrorising' for workers, claimed that the crisis and legislative changes have changed the balance of power: employers are now more demanding and much less willing to accept union presence and collective action. As a result, workers are experiencing work intensification, lower pay, long working hours and work-related injuries (Rizospastis newspaper, 2017a). A 29-year-old union member, employed as a waitress on a six-month contract in a large non-union 5-star Mykonos hotel, gave an account typical of the seasonal workers in our sample:

I had to work shifts from 6.00 am to $1.00 \mathrm{pm}$ and then from $7.00 \mathrm{pm}$ until $1.00 \mathrm{am}$. It is 60 to 70 hours work per week for a salary of around $€ 1,200$ per month, so when friends tell me you 
are lucky, I don't really agree since if the sector agreement was implemented my salary would be much higher, probably double that. Working conditions are also very bad. Because of the lack of sleep, I had gained a lot of weight. There was so much hyper-tension and pressure that I could not sleep properly.

This presents a stark contrast to the working conditions and pay rates that employees experienced in the pre-crisis period. In that respect, Greece has moved towards the predominant model of employment relations in tourism internationally (Willis, 2005).

\section{THE IMPACT OF SECTORAL CONTEXT: THE ROLE OF INSTITUTIONAL DEROGATION AND CONVERSION}

Renewal of sector agreements on condition of wage cuts was rejected by unions in those economic sectors (metal and food and drink manufacturing) historically characterised by adversarial industrial relations. But in the hotel industry the Federation continued the tradition of moderation and cooperation, renewing the agreement despite having to accept significant pay cuts. Although institutional continuity has been portrayed as positive by employers and unions, it is a case of institutional conversion, since it produces different outcomes from those envisaged when this institution started. Thus, the 2011 sector agreement specified no pay increase and the 2012 agreement a 15 per cent pay cut for two years (POEET, 2012). Since then, the agreements have conceded either small or zero pay rises. Drawing on the law 3986/2011, the 2018 sector agreement altered the regulation of working time, specifying that it is calculated over a period of four months during which workers can be employed (with extra pay) for additional hours per day and one day more per week, compensating for these with days off in less busy periods. This was a long-standing employers' demand, confirming that, unlike 1992-2008, when changes to collective bargaining were partly the initiative of unions, much of the bargaining agenda since the crisis has represented employers' objectives (Koukiadaki and Grimshaw, 2016, 58). 
This underscores the argument of Baccaro and Howell (2017), among others, that the institutions are plastic and their stability of form might be combined with a changing function, producing unfavourable outcomes for workers (Thelen, 2009). Industry-specific interests such as the promotion of working-time flexibility were incorporated into the sector agreements, revealing the extent to which employers' demands were served not only by deregulation but also by significant changes in the meaning and content of sectoral regulation. During a group interview of Syndicate members (in a large 5-star hotel in Athens), this danger was recognised, with the Federation accused of selling out workers' rights. In 2012 the Syndicate had organised two strikes, demanding improvements in sector agreements such as on working conditions, working hours and flexible contracts (Syndicate HotelsTourism Attika, 2012).

Institutional derogation was another process through which hotel employers exempted themselves from rules in the sector agreement by using the new legal framework. The law 4024/2011 suspended the legal favourability and extension principles, thus establishing a regulatory context aligned with the state's goal of internal devaluation. With the suspension of the favourability principle, businesses could exempt themselves from higher (sectoral) levels using methods such as firm-level agreements and withdrawing from their employers' association as only members of the signatories were obliged to abide by its terms (Koukiadaki and Kretsos, 2012, 292). As for the first, the number of companylevel agreements skyrocketed, reaching 976 in 2012 (compared to 227 in 2010) across the economy, twenty per cent of which was concluded by hotels. For example, we found hotels in Kos and Crete that had concluded firm-based agreements, reducing pay to levels close to, or at, the NMW (Rizospastis newspaper, 2017b). This trend did not last long: many workplaces were too small to establish bargaining arrangements or monitor their implementation (unlike in manufacturing). There were also cases where the local employers' association (such as in Rhodes) signed a local agreement with the union that deviated from the sector agreement and allowed no days off during a one-week period. According to a Federation-affiliated union president in a large 5-star Athens hotel, the main trend was for seasonal and smaller (mainly budget) hotels to resort to individual contracts whose 
content in most cases was not determined by the sector agreement but by individual negotiations, with employers having the upper hand.

The abolition of the extension principle was a major blow to sectoral regulation; employers were no longer obliged to apply the agreement to all employees. Many employers even withdrew from regional hotel associations, as in Chalkidiki (northern Greece), since with the suspension of extension there was now no legal obligation to operate the agreement if employers were not association members. Only 10 per cent of hotels were still following the sector agreement in 2014 (compared to 80 per cent prior to 2009). According to the SETE research director, hotels that are members of SETE were the most likely to follow the agreements: to avoid bad publicity, maintain social peace and secure high productivity. The Federation president clarified that large well-established upper-market brand hotels in Athens were implementing the agreement and pushing the smaller ones to do likewise in an attempt to eliminate unfair competition practices, regularly engaged in by seasonal hotels (even though many of these were SETE members). That most of those implementing the agreement were unionised is a crucial reason why they complied, although we found that these hotels also used outsourcing and agency work to remove some workers from the agreement's coverage. Workers with higher skills, and longer service, employed by unionised large 5-star hotels (mainly in Athens) that operated all year round, were more likely to be covered by the agreement and therefore have better working conditions than other workers - albeit all employment terms and pay levels had deteriorated to varying extents since the crisis.

Institutional derogation was also facilitated by the underfunding (due to austerity) of enforcement agencies. Similar to other sectors, Greek hotels used loopholes to overcome existing rules and sectoral regulation (Efsyn newspaper, 2015). Many workers did not react to such violation of employment rights as the non- or partial implementation of sector agreements, feeling that this would constitute a betrayal of the positive relations they had developed with their employer before the crisis. The most common method used was described by a 45 -year-old female (full-time permanent but non-union) cleaner at a unionised 5-star Athens hotel: 'In 2008, unsocial hours were fully compensated according 
to the sector agreement, so my salary could reach $€ 1,500$ per month if I worked unsocial hours. Nowadays, regardless of the working hours I do, my salary is fixed at $€ 800-900$.'

Institutional derogation together with institutional conversion has made it harder for unions to defend working rights, especially in small and medium-sized hotels that lack workplace unions. Here, employees have been victimised and forced to either accept managerial decisions or face dismissal and non-renewal of contracts. Reduced workloads and unstable schedules were also used widely to punish those reacting to the degradation of their working conditions. A 26-year-old seasonal waitress in a medium-sized 5-star non-union hotel in Santorini explained that her refusal to accept a salary below the sector agreement reduced significantly her chance of keeping her job, with more compliant employees preferred. According to a 48-year-old male union member, a seasonal receptionist in a medium-sized 5-star Crete hotel, the lack of union presence in most island hotels, the increased difficulty in developing collective organization due to the limited contract duration and the short-term horizons of most seasonal workers were the main reasons for a more aggressive management style in seasonal hotels compared with those in Athens. Structural factors, such as seasonality and tips, were also noted by our interviewees as limiting the collective consciousness needed for action to defend sectoral regulation. A Syndicate member stressed that that during peak seasons it was extremely difficult even for activists to undertake union activity due to very high work intensity and very long working hours. This helps to explain why workers in non-union and seasonal upper market hotels were faring worse than their counterparts in unionised and all-year-round hotels in Athens. As found in other studies (Lloyd et al., 2013; Lloyd and Payne, 2018) we did not observe any significant impact of product market strategies on wages and working conditions, with most differences related to workplace union presence, labour market position and workers' contractual status.

According to a Syndicate union president in a large 5-star Athens hotel, some occupational groups, such as cooks and receptionists, had more chance of a career than those employed by budget and smaller hotels and therefore individualised narratives and choices were likely to prevail among them. Collective action was further impeded by those with an opportunist attitude, such as students or graduates, who intended to work only for a limited period before finding other employment. 
Consequently, promoting collective identities and organising the new generation of hotel workers has been very challenging. Yet, although working conditions have deteriorated across the board, the enforcement of sector agreements was higher in large upper-market hotels in Athens - mainly because of the more active unions there - and therefore older hotel workers were faring much better than their newly-hired young counterparts and those employed on the Greek islands. Another characteristic reported by many interviewees was that some employers were willing to offer better wages and benefits on an individualised level reflecting performance and obedience - but only in order to reduce the influence of collective organisation and incorporate workers into company goals.

\section{DISCUSSION AND CONCLUSIONS}

This study reveals that despite similarities internationally, in the technical and market contexts of the hotel industry, the Greek experience differed from most other countries prior to the crisis, challenging accounts that see hotel work as invariably and inherently 'bad' and low-paid (Wood, 1997; Lucas, 2004; Knox, 2010; Baum, 2019). Aspects of the wider power context (Dunlop, 1958), such as employment protection legislation, multi-employer agreements and union presence, were then predominant in the Greek hotel industry, affecting positively remuneration and employment security. Even challenging industry features such as seasonality, flexibility and informality (Adam-Smith et al., 2003) were more socially integrated and less insecure than in other countries because their content was regulated by sector agreements (Gialis et al., 2017; Robinson et al., 2019). There were attempts to liberalise labour law prior to the crisis, to provide more flexibility to employers, but counter-trends, underpinned by the sector agreement and union activity, secured wages and conditions not substantially different from most other sectors - a situation not generally found in other countries.

This pattern changed substantially after the crisis. Under pressure from the Troika, Greek governments since 2010 have adopted a clear deregulatory trajectory, 'internal devaluation', through which the unions' role has been undermined and sectoral regulation significantly dismantled. Against the background of limited economic losses compared to other sectors, the main social actors in the 
hotel industry deviated from the new norm (of not renewing sector agreements) and continued their tradition of co-operation and lack of adversarialism. This development emphasises the importance of the sector as a site of analysis, given the employment relations variation between sectors within a country. But labour market reforms offered hotel employers many ways to avoid implementing the sector agreement, enabling them to impose working conditions and pay levels that corresponded to those of other sectors and the economy average. Consequently, our study has shown that, for Greece at least, the sector is not now the defining unit of analysis as found in other accounts of hotel work, since the latter has followed the deregulated trajectory of the Greek employment model.

By listening to the voices of a variety of workers across the industry, we have shown that even large hotels started using flexible work extensively in order to circumvent sectorally-agreed terms, by taking newly hired workers such as agency staff out of the sector agreement even when still formally committed to it. Many 5-star hotels in Athens were cautious about this use of flexible work, though, since in certain occupations (front-line staff) they preferred to hire permanent workers because of the need for service quality (Schlesinger and Heskett, 1992; Korczynski, 2002). Overall, though, the insecurity reported by our interviewees shows that institutional continuity of the sector agreement has not stopped working experiences and wage levels deteriorating since the crisis.

The resistance to such trends, observed before the crisis, was eroded as the confluence of labour market and labour law changes ensured a more adaptable, fearful and flexible labour force hardly protected by state regulation. High labour turnover had been a consistent feature of the industry, but the crisis increased the pool of workers available. Hotels then started threatening existing employees or recruiting new ones on inferior terms. Rising numbers of agency and temporary contracts contributed to that process since organising such workers was difficult and unions were sometimes reluctant to represent them. The absence of workplace unions in most small and medium workplaces, and in many tourist areas, intersected with the industry's particular combination of interpersonal relations, seasonality, short-termism, tips and (now) employees' fear, to make the enforcement of the sector agreement and upholding employment rights more difficult. 
In line with previous studies of the hospitality industry (hotels and cafes), the differences we found were not the result of product market strategies but were mainly related to union presence (Lloyd et al., 2013; Lloyd and Payne, 2018), though seasonality also played a role. The mix of factors exacerbated existing divisions within the workforce, so workers were more dependent on their own contractual status and the presence of unions to be able to resist the tsunami of deregulation and derogation. Although collective action was not absent, with unions still organising occasional strikes, conditions were better mainly in hotels with an active union presence. The Greek hotel industry now resembles that of other countries where the improvement of working conditions and wages relies almost entirely on the presence and density of workplace unions (Hirsch et al., 2001; Bernhardt et al., 2003; Vanselow et al., 2010; Lloyd and Payne, 2018).

The Greek experience since 2010 is an extreme version of Baccaro and Howell's (2017) European ‘trajectories of neoliberal transformation'. Within the space of a few years - from the Troika-imposed changes of 2010 to, at the time of writing, the latest (2018) sector agreement - the Greek hotel industry has undergone a compressed period of convulsive change. From following closely the Greek national model, albeit with the industry's particular features, hotel workers have, to a large extent, been catapulted into the mainstream of the low-wage, highly casualised industry internationally. Despite institutional continuity, the national form of deregulation in Greece, reinforced by the industry's own derogation, prevents hotel workers from taking advantage of buoyant tourism. The Greek hotel industry provides a textbook example of institutional conversion, where the sector agreement fulfils a very different function to that of only ten years ago. As a result, Greek hotel workers' experience mirrors that of workers in other economic sectors who have suffered more from the crisis.

Yet, a not insignificant number of employers and the main union in the industry still consider, for different reasons, the alternative of walking away from the agreement unpalatable. Even now, with the traumatic experience of the last decade, the sector agreement covering Greek hotel workers provides a standard that, at some point, could be improved and extended through institutional re-conversion. As the pre-crisis period shows, Greek hotel employers would not have been able on their own to promote 
industry-wide demands and avoid sectoral regulation, without the opportunities granted by the changing power context. For this reason, any improvement to the pay and conditions of hotel workers seems to be reliant on re-regulation at national level. This, though, is unlikely without internal pressure, given Greek governments' ongoing commitment to labour market reforms (with the IMF as the most significant external driver). One possible route to re-regulation is through the revitalisation of the trade union movement. The proven ability of Greek militant unions to organise collective actions might push government, during favourable economic conditions, to reverse some of the national deregulation, opening a space for unions to negotiate improvements in the sectoral agreement. But, without the legislative support required to reinstate the favourability and extension principles so the sector agreement applies whatever the workers' contractual status, this will surely be an uphill task.

\section{Acknowledgments}

We are grateful to Melanie Simms, Paul Marginson and Gregoris Ioannou for advice on an early draft and to the editor and referees for helpful comments. 


\section{References}

Adam-Smith, D., G. Norris and S. Williams (2003), 'The implications of the National Minimum Wage for work and employment in the hospitality industry', Work, Employment and Society, 17, 1, $29-47$.

Appelbaum, E. (2010), 'Institutions, firms, and the quality of jobs in low-wage labour markets', in Gautie, G. and J. Schmitt (eds), Low-wage work in the wealthy world (New York, Russell Sage Foundation).

Arnholtz, J., G. Meardi and J. Oldervoll (2018), 'Collective wage bargaining under strain in northern European construction: resisting institutional drift?', European Journal of Industrial Relations, 24, 4, $341-356$.

Baccaro, L. and C. Howell (2017), Trajectories of neoliberal transformation: European industrial relations since the 1970s (Cambridge, Cambridge University Press).

Baum, T. (2006), Human resource management for tourism, hospitality and leisure: An international perspective (London, Thomson Learning).

Baum, T. (2019), 'Hospitality employment 2033: A backcasting perspective', International Journal of Hospitality Management, 76, 45-52.

Bechter, B., B. Brandl and G. Meardi (2012), 'Sectors or countries? Typologies and levels of analysis in comparative industrial relations', European Journal of Industrial Relations, 18, 3, 185-202.

Bernhardt, A., L. Dresser and E. Hatton (2003), 'The coffee pot wars: unions and firm restructuring in the hotel industry', in Appelbaum, E., A. Bernhardt and R. Murnane (eds), Low-wage America: how employers are reshaping opportunity in the workplace (New York, Russell Sage Foundation). 
Berntsen, L. and N. Lillie (2015), 'Breaking the law? Varieties of social dumping in a pan-European labour market', in M. Bernaciak (ed.), Market expansion and social dumping in Europe (London, Routledge).

Brown, D. and A. Crossman (2000), 'Employer strategies in the face of a national minimum wage: an analysis of the hotel sector', Industrial Relations Journal, 31, 3, 206-219.

Cañada, E. (2018), 'Too precarious to be inclusive? Hotel maid employment in Spain', Tourism Geographies, 20, 4, 653-674.

Casado-Díaz, J. M. and H. Simon (2016), 'Wage differences in the hospitality sector', Tourism Management, 52, 96-109.

Currie, D. and P. Teague (2017), 'The Eurozone crisis, German hegemony and labour market reform in the GIPS countries', Industrial Relations Journal, 48, 2, 154-173.

Doellgast, V. and I. Greer (2007), 'Vertical disintegration and the disorganization of German industrial relations', British Journal of Industrial Relations, 45, 1, 55-76.

Dunlop, J. T. (1958), Industrial relations systems (New York, Holt).

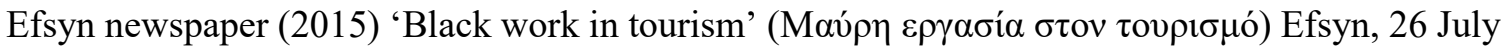
2015.

European Commission (2010), 'Greek programme of economic adjustment', Occasional Papers 61 (Brussels, European Commission Directorate-General for Economic and Financial Affairs).

Gialis, S., M. Tsampra and L. Leontidou (2017), ‘Atypical employment in crisis-hit Greek regions: local production structures, flexibilization and labour market re/deregulation', Economic and Industrial Democracy, 38, 4, 656-676. 
Godino, A. and O. Molina (2019), 'Who overcomes collective bargaining? Outsourcing practices, regulatory framework and facility management in Spain', Country Report-RECOVER project https://ddd.uab.cat/record/202073

Hirsch, B. T., D. A. Macpherson and W. G. Vroman (2001), 'Estimates of union density by state', Monthly Labor Review, 124, 7, 51-55.

ILO (2010), 'Developments and challenges in the hospitality and tourism sector', Issues paper for discussion at the Global Dialogue Forum for the Hotels, Catering, Tourism Sector (Geneva, International Labour Organization).

INSETE (2018), 'Employment in tourism and the other sectors of the Greek economy 2008-2017' (H

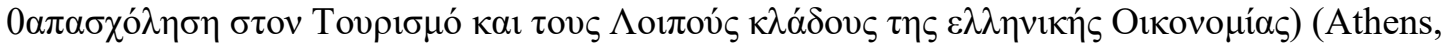
Intelligence Greek Tourism Confederation).

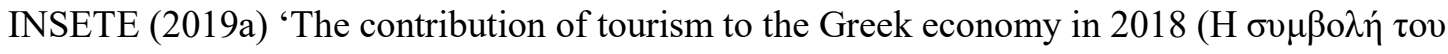

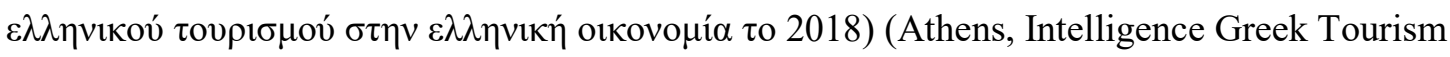
Confederation).

INSETE (2019b), 'Employment in tourism and the other sectors of the Greek economy 2009-2018'

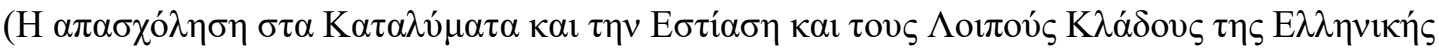
Oıкоvouías, 2009-2018) (Athens, Intelligence Greek Tourism Confederation).

ITEP (2018), 'Developments in the basic figures of Greek Hotel Industry' (Oı $\varepsilon \xi \varepsilon \lambda \hat{\xi} \xi \varepsilon 1 \zeta ~ \sigma \tau \alpha \beta \alpha \sigma \iota \kappa \alpha ́$

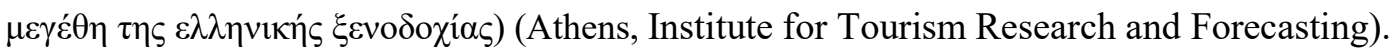

Jaehrling, K. and P. Méhaut (2012), 'Varieties of institutional avoidance: employers' strategies in lowwaged service sector occupations in France and Germany', Socio-Economic Review, 11, 4, 687-710. Karamessini, M. (2008), 'Still a distinctive southern European employment model', Industrial Relations Journal, 39, 6, 510-531. 
Karamessini, M. (2012), 'Sovereign debt crisis: an opportunity to complete the neoliberal project and dismantle the Greek employment model', in S. Lehndorff (eds), A triumph of failed ideas. European models of capitalism in the crisis (Brussels, ETUI).

Knox, A. (2010), 'Lost in translation': an analysis of temporary work agency employment in hotels', Work, Employment and Society, 24, 3, 449-467.

Korczynski, M. (2002), Human resource management in the service sector (Basingstoke, Palgrave).

Koukiadaki, A. and L. Kretsos (2012), 'Opening Pandora's Box: The sovereign debt crisis and labour market regulation in Greece', Industrial Law Journal, 41, 3, 276-304.

Koukiadaki, A. and D. Grimshaw (2016), 'Evaluating the effects of the structural labour market reforms on collective bargaining in Greece', Conditions of Work and Employment Series 85 (Geneva, International Labour Organization).

Lai, P. C., E. Soltani and T. Baum (2008), 'Distancing flexibility in the hotel industry: the role of employment agencies as labour suppliers', International Journal of Human Resource Management, 19, 1, 132-152.

Lloyd, C., C. Warhurst and E. Dutton (2013), 'The weakest link? Product market strategies, skill and pay in the hotel industry', Work, Employment and Society, 27, 2, 254-271.

Lloyd, C. and J. Payne (2018), 'Hard times in latte land? Analysing pay and working time in the café industry in France, Norway and the UK', Economic and Industrial Democracy, 0143831X18809887.

Lucas, R. (2004), Employment relations in the hospitality and tourism industries (London, Routledge).

Marginson, P. and C. Welz (2015), 'European wage-setting mechanisms under pressure: negotiated and unilateral change and the EU's economic governance regime', Transfer: European Review of Labour and Research, 21, 4, 429-450. 
Meardi, G. (2004), 'Short circuits in multinational companies: the extension of European Works Councils to Poland', European Journal of Industrial Relations, 10, 2, 161-178.

Papanikopoulos, D., D. Katsoridas, G. Kollias and V. Dermani (2018), 'The strike phenomenon in

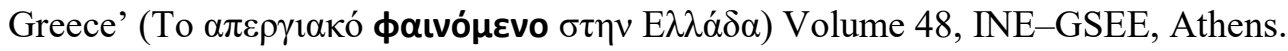

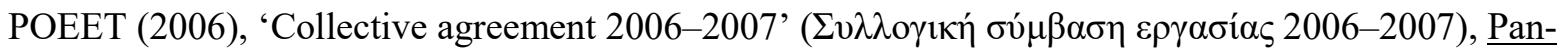
Hellenic Federation of Food Workers and Tourism Employees https://poeet.gr/rapt/files/sse/hotels/h_a_2006-2007.pdf

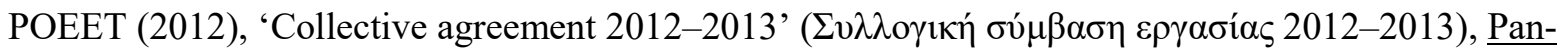
$\underline{\text { Hellenic Federation of Food Workers and Tourism Employees }}$ https://poeet.gr/rapt/files/sse/hotels/h_a 2012_2013.pdf Rizospastis newspaper (2017a), 'Rise up the action ahead of the 20 July Strike' ( $\kappa \lambda \mu \alpha \dot{\alpha} \kappa \omega \sigma \eta \tau \eta \varsigma$

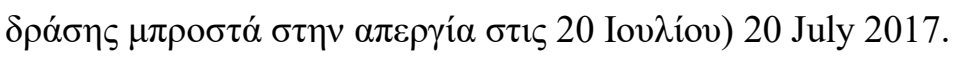

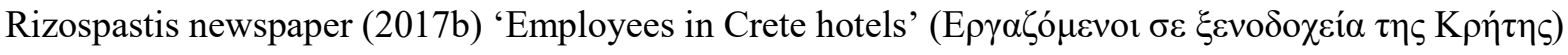
16 July 2017.

Robinson, R. N., A. Martins, D., Solnet and T. Baum (2019), 'Sustaining precarity: critically examining tourism and employment', Journal of Sustainable Tourism, 27, 7, 1008-1025.

Schlesinger, L. A. and J. L. Heskett (1992), 'De-industrializing the service sector: a new model for service firms', Advances in Services Marketing and Management, 1, 159-176.

Streeck, W. and K. Thelen (2005), 'Introduction: institutional change in advanced political economies', in Streeck, W. and K. Thelen (eds), Beyond continuity: institutional change in advanced political economies (Oxford, Oxford University Press).

Syndicate Hotels-Tourism Attika (2012), 'Strikes' (A $\pi \varepsilon \rho \gamma i ́ \varepsilon \varsigma) ~ h t t p: / / h w u . g r / ? p a g e \_i d=308$ Thelen, C. (2009), 'Institutional change in advanced political economies', British Journal of Industrial Relations, 47, 3, 471-498. 
TV Focus on People (8 August 2017), 'Greece: modern slavery in the tourism sector', accessed 15 March 2019. https://www.dw.com/en/greece-modern-slavery-in-the-tourism-sector/av-40280152

Vanselow, A., C. Warhurst, A. Bernhardt and L. Dresser (2010), 'Working at the wage floor: hotel room attendants and labor market institutions in Europe and the United States', in Gautie, G. and J. Schmitt (eds), Low-wage work in the wealthy world (New York, Russell Sage Foundation).

Warhurst, C., C. Lloyd, and E. Dutton (2008), 'The National Minimum Wage, low pay and the UK hotel industry', Sociology, 42, 6, 1228-1236.

Wills, J. (2005), 'The geography of union organising in low-paid service industries in the UK: lessons from the T\&G's campaign to unionise the Dorchester Hotel, London', Antipode, 37, 1, 139-159.

Wood, R. C. (1997), Working in hotels and catering (London, International Thomson Business Press). Zambarloukou, S. (2010), 'Ownership, corporate governance and industrial relations in the banking and telecommunications sectors: the case of Greece', Industrial Relations Journal, 41, 3, 233-248.

Zampoukos, K. and D. Ioannides (2011), 'The tourism labour conundrum: agenda for new research in the geography of hospitality workers', Hospitality and Society, 1, 1, 25-45. 